\title{
Influence of Different Levels of Irrigation and Fertilizers on Yield and Cost Economics of Papaya ( $c v$. Red Lady) under Open and Protected Condition
}

\author{
Vinod Godi $^{1 *}$, Mahabaleshwar Hegde ${ }^{1}$, A. Vidya ${ }^{1}$, M. N. Thimmegouda ${ }^{2}$, \\ C. T. Subbarayappa ${ }^{3}$, B. Shivanna ${ }^{4}$ and B. G. Hanamantharaya ${ }^{1}$ \\ ${ }^{1}$ Department of Horticulture, ${ }^{2}$ Department of Agronomy, ${ }^{3}$ Department of soil science \& \\ Agriculture chemistry, ${ }^{4}$ Department of Entomology, UAS, GKVK, Bangalore, India \\ *Corresponding author
}

\begin{abstract}
A B S T R A C T

\begin{tabular}{|l|}
\hline Ke y w o r d s \\
$\begin{array}{l}\text { Papaya, Drip } \\
\text { irrigation, Yield } \\
\text { parameters, Cost } \\
\text { economics, RDF, E } \\
\text { pan, Protected } \\
\text { condition }\end{array}$ \\
\hline Article Info \\
\hline $\begin{array}{l}\text { Accepted: } \\
\text { 22 October } 2020 \\
\text { Available Online: } \\
\text { 10 November } 2020\end{array}$ \\
\hline \hline
\end{tabular}

An experiment was carried out to study the growth, yield and cost economics of papaya (Carica papaya L.) $c v$. Red lady as influenced by different irrigation and fertilizer levels. This experiment was conducted at PFDC (Precision farming development centre), Department of Horticulture, UAS, GKVK, Bengaluru during 2018-19 and 2019-20. The experiment was laid out with twelve different treatments replicated thrice. The spacing followed was $1.8 \mathrm{~m}$ x $1.8 \mathrm{~m}$. The highest yield parameters under protected and open conditions revealed that, significantly the highest yield per plant $(77.70 \mathrm{~kg})$ and yield per hectare (239.77 tons) was achieved under protected conditions, while an average yield of $39.64 \mathrm{~kg}$ per plant and 122.32 tons yield per hectare was obtained under open field conditions with the same irrigation and fertilizer levels @ 50\%,80\% and $100 \%$ E pan $(\mathrm{mm} /$ day $)+125$ per cent recommended dose of fertilizers. The highest cost benefit ratio in papaya $c v$. Red lady grown under open filed condition was 1:2.35 with the application of $50 \%, 80 \%$ and $100 \% \mathrm{E}$ pan (mm/day) +125 per cent RDF, whereas, for every one rupee invested the cost benefit ratio was to the extent of 1:3.03grown under naturally ventilated polyhouse structure, whereas the least vegetative, yield parameter and also lesser cost benefit ratio was observed in $\mathrm{T}_{1}-\mathrm{I}_{1} \mathrm{~F}_{1} 30 \%, 50 \%$ and $60 \% \mathrm{E}$ pan(mm/day) $+75 \% \mathrm{RDF}$ at $90,180,270,360,450$ and 540 days after transplanting under open field and protected condition respectively.
\end{abstract}

\section{Introduction}

Papaya (Carica papaya L.) is a fast growing, short lived, semi woody and herbaceous perennial tree. It is grown commercially for its fruits which are consumed both as fresh fruit and processed products. The plant grows to a height of 10-12 feet. Next to mango and pineapple papaya is the most cultivated fruit in the world consider to tropical climate, which occupies 15.36 per cent of total tropical fruit production in the world.

Papaya is largely cultivated in Australia, Hawaii, India, Sri Lanka, Myanmar, Taiwan, Brazil, Peru, Puerto Rico, Florida, Texas, California, South Africa and Kenya. In India, it is successfully grown all over the country 
and available round the year. This occupies 1.8 per cent of the total fruit crop area and contributes 6.3 per cent of total fruit production in India. This is cultivated in an area of 133.36 thousand hectares with a production of 5639.30 thousand MT.

The average productivity is 42.3 tons per hectare (Anon., 2018). The important papaya growing states in India are Andhra Pradesh, Gujarat, Maharashtra, Karnataka, Madhya Pradesh, Bihar, West Bengal, Tamil Nadu, Kerala, Assam and Rajasthan, where ideal climatic conditions are available for its growth and production.

The cultivated area under this crop in Karnataka State is 5,800 hectares with the total production of 4,19,300 metric tonnes with a productivity of 72.3 metric tonnes per hectare (Anon., 2018), due to its continuous vegetative growth, flowering and fruiting habits. Papaya requires high level of nutrients in a study the extent of nutrients removed by the estimated plant at harvest have been to be $305 \mathrm{~kg}$ of $\mathrm{N}_{2} \mathrm{O}, 103 \mathrm{~kg}$ of $\mathrm{P}_{2} \mathrm{O}_{5}, 524 \mathrm{~kg}$ of $\mathrm{K}_{2} \mathrm{O}, 327 \mathrm{~kg}$ of $\mathrm{Ca}$ and $183 \mathrm{~kg}$ of $\mathrm{Mg}$ per hectare (Veerannah and Selvaraj, 1984).

Papaya fruit is the rich source of minerals, vitamins $\mathrm{A}, \mathrm{B}, \mathrm{B}_{2}$ and $\mathrm{C}$. It also contains calcium, iron, and phosphorus. The leaves of papaya have alkaloid called caprine and is widely used in Ayurveda. Its sap is used in the treatment of warts, caruncle, corns and calluses. Papaya sap is also used in treating psoriasis and ringworm infections. The latex extracted form fruit at $3 / 4^{\text {th }}$ maturity, which is rich in papain (an active enzyme) has been used as meat tendering. Meat gets cooked faster by adding a few pieces of papaya in curries. Raw papaya has the ability to kill intestinal worms. Tasty jams are made from ripe papaya. Tutti-frutti, used in bakery industry, is made from raw papaya.
Papaya $c v$. Taiwan red lady 786 is a gynodioecious variety, which has sweetest and red crispy flecks having good keeping quality. Hence this cultivar is widely used as a table fruit. Papaya is popularly grown in India due to its suitability to tropical environmental conditions. The average fruit weight 1.5 to 2.0 $\mathrm{kg}$. Fruit setting starts at on the stem about 70 $\mathrm{cm}$ above soil and mostly by nine months from the seedling stage. The plants produce about 35 fruits per season and fruit ship well. First year production is larger than second year production. Each gram of seed contains about 50 - 80 seeds. About 50 to $80 \mathrm{~g}$ seeds are required to get planting material sufficient to take up planting per hectare.

\section{Materials and Methods}

The present investigation entitled "Studies on standardization of irrigation and fertilizer levels on growth, yield and quality of papaya ( $c v$. Red Lady) under protected and open field conditions" was carried out at the Precision Farming Development Centre, Department of Horticulture, Gandhi Krishi Vignana Kendra, University of Agricultural Sciences, Bangalore during the period from July, 2018 to December 2019. The materials used, techniques adopted and procedures followed during the investigation are listed here under.

The experimental site was located at $12^{0} 58$ 'northlatitudeand $77^{0} 35^{\prime}$ 'eastlongitudew ithanaltitude of $930 \mathrm{~m}$ above Mean Sea Level (MSL). The soil of the experimental area was red sandy loam with uniform fertility having $\mathrm{pH}$ of 6.4 to 6.8. The experiments were carried out with the main objective of studying the effect of irrigation and fertilizer levels on growth, yield and quality of papaya under open field and protected conditions of ventilated poly house structure.

The average of forty-seven years weather data (1972-2019) at Zonal Agriculture Research 
Station, GKVK, Bengaluru revealed that the average annual rainfall of the station is 922.0 $\mathrm{mm}$ and the major portion of rain is received during the months of July to October. The maximum amount of rainfall was received during September and October months. The average air temperature ranged from $26.1^{\circ} \mathrm{C}$ to $33.7^{\circ} \mathrm{C}$, while the average minimum air temperature varied between $13.9^{\circ} \mathrm{C}$ to $20.5^{\circ} \mathrm{C}$. Monthly mean relative humidity ranged from 75.0 to 88.8 per cent and mean sunshine hours varied from 4.4 to 9.5 hours depending upon seasons.

The observations were recorded on yield parameters like number of flowers per plant, number of fruits per plant, indivual fruit weight $(\mathrm{kg})$, fruit yield per plant $(\mathrm{kg})$ and fruit yield per hector $(\mathrm{t} / \mathrm{ha})$ during the crop growth at 90,180,270,360,450 and 540 DAT under open field condition and work out the cost economics both open and protected conditions.

\section{Results and Discussion}

Influence of different levels of drip irrigation and fertilizers on yield and yield attributes under open field and protected conditions

The data pertaining to the reproductive parameters such as number of flowers per plant, number of fruits per plant, fruit yield per plant $(\mathrm{kg})$ and fruit yield per hectare (tons)recorded during the crop growth period under both open and protected condition are presented in Table 1 \& 2 and graphically depicted in Figure 1 and 2 respectively.

\section{Number of flowers per plant under open field condition}

The highest number of flowers per plant (64.21) in a period of 540 days (depicted in Fig.1) was produced by the plants irrigated with drip @ 60\%,90\% and 120\% E pan $\left(\mathrm{I}_{4}\right)$. The next best irrigation level @ 50\%,80\% and $100 \% \mathrm{E}$ pan resulted in production of 61.40 flowers per plant. The lowest number of flowers (56.12 flowers/plant) was noticed at irrigation level $\left(\mathrm{I}_{1}\right)$ i.e $30 \%, 50 \%$ and $60 \% \mathrm{E}$ pan. The plants responded similarly to the varied levels of fertilizers wherein $\mathrm{F}_{3}$ level i.e 125 per cent RDF registered the highest number of flowers (61.88 per plant) followed by the fertilizer level at recommended dose of fertilizers (59.70 flowers/plant). The lowest number of flowers per plant (58.84) was produced when 75 per cent RDF were applied.

In the interaction effect, the lowest number of flower per plant (55.02) was recorded in the plants receiving irrigation level @ 30\%,50\% and $60 \%$ E pan combined with fertilizer level of $\mathrm{F}_{1} @ 75$ per cent $\mathrm{RDF}\left(\mathrm{I}_{1} \mathrm{~F}_{1}\right)$ whereas, the significantly the highest number of flower (67.14) per plant was recorded due to combined irrigation level @ 60\%,90\% and $120 \% \mathrm{E}$ pan +125 per cent $\mathrm{RDF}\left(\mathrm{I}_{4} \mathrm{~F}_{3}\right)$. This was followed by the treatment involving irrigation@60\%, 90\% and 120\% E pan + fertilizer level at recommended dose $\left(\mathrm{I}_{4} \mathrm{~F}_{2}\right)$ the number of flowers produced per plant was 63.19.

\section{Number of flowers per plant under protected condition (Table 2)}

The highest number of flowers per plant (88.85) was noticed in the plants which received irrigation level of @ 60\%, 90\% and $120 \% \mathrm{E}$ pan. This was followed by irrigation level @ 50\%, 80\% and 100\% E pan (84.09 flowers/plant). The lowest number of flowers per plant (77.21) was recorded in the plants supplied with irrigation level $\left(\mathrm{I}_{1}\right)$ @ 30\%, $50 \%$ and $60 \%$ E pan. With respect to fertilizer levels, the lowest number of flowers per plant (80.88) was observed in the plants receiving fertilizer level of $F_{1}$ i.e recommended dose of 
fertilizers. At fertilizer level $F_{2}$ i.e 125 per cent $\mathrm{RDF}$, the plants produced 83.03 flowers per plant whereas, significantly the highest number of flowers per plant (84.64) was recorded under fertilizer level@ 150 per cent $\operatorname{RDF}\left(\mathrm{F}_{3}\right)$.

The plants supplied with irrigation @ 60\%, $90 \%$ and $120 \% \mathrm{E}$ pan combined with 150 per cent $\mathrm{RDF}\left(\mathrm{I}_{4} \mathrm{~F}_{3}\right)$ registered significantly the highest number of flowers per plant (91.48) followed by the treatment with irrigation @ 60\%,90\% and $120 \% \mathrm{E}$ pan +125 per cent RDF $\left(\mathrm{I}_{4} \mathrm{~F}_{2}\right)$ where the number of flowers produced per plant was 88.78 . However, the lowest number of flowers per plant (74.14) was seen in the lower level of irrigation and fertilizers $\left(\mathrm{I}_{1} \mathrm{~F}_{1}\right) @ 30 \%, 50 \%$ and 60\% E pan + recommended dose of fertilizers.

The above observations highlighted under subheading also revealed that the pattern of flowering in papaya plants appears compact as the plant height is restricted under open field condition when compared to polyhouse conditions. This is because internodal length between two leaves is constricted under open condition. Whereas under polyhouse, the plant height is more due to increased therefore internodal length.

\section{Percent of fruit set under open field condition}

The plants receiving irrigation level $\left(\mathrm{I}_{3}\right)$ @ $50 \%, 80 \%$ and $100 \% \mathrm{E}$ pan resulted in significantly the highest percentage fruit set (66.67) followed by treatment with irrigation level $\left(\mathrm{I}_{4}\right) @ 60 \%, 90 \%$ and $120 \%$ E pan $(63.29 \%)$. The lowest percentage of fruit set (52.37) was noticed in the plants receiving irrigation@30\%, 50\% and 60\% E pan $\left(\mathrm{I}_{1}\right)$. Plant receiving highest dose of fertilizer $\left(\mathrm{F}_{3}\right)$ @ 125 per cent RDF resulted in significantly the higher percentage of fruit set per plant (61.56). This was followed by fertilizer level
$\left(\mathrm{F}_{2}\right)$ i.e recommended dose of fertilizer $(60.38$ $\%)$ and the least percentage of fruit set (57.58) was recorded in the plants receiving lower level of fertilizer i.e 75 per cent $\operatorname{RDF}\left(\mathrm{F}_{1}\right)$.

The effect of interactions between irrigation and fertilizer levels showed a significant influence on fruit set percentage. The treatment $\mathrm{I}_{3} \mathrm{~F}_{3}$ i.e $50 \%, 80 \%$ and $100 \% \mathrm{E}$ pan and 125 per cent RDF was resulted in fruit set percentage of 68.57 which, was highly significant over the other treatments. This was followed by treatment $\mathrm{I}_{3} \mathrm{~F}_{2} @ 50 \%, 80 \%$ and $100 \% \mathrm{E}$ pan and 125 per cent $\operatorname{RDF}(66.53 \%)$. The lowest percent fruit set (50.76) was recorded in the plants receiving $\mathrm{I}_{1} \mathrm{~F}_{1}$ i.e $30 \%$, $50 \%$ and $80 \% \mathrm{E}$ pan and 75 per cent RDF under open field condition.

\section{Percent fruit set under protected condition}

The highest per cent fruit set (75.82) was recorded in the plants irrigated with drip @ 50\%, 80\% and 100\% E pan. The next best treatment effect was at the irrigation level @ $60 \%, 90 \%$ and $120 \% \mathrm{E}$ pan which resulted in 66.76 percent fruit set. The lowest fruit set $(59.88 \%)$ was noticed with the irrigation level i.e 30\%, 50\% and 60\% $\mathrm{E}$ pan $\left(\mathrm{I}_{1}\right)$. The plants responded similarly to the medium dose of fertilizer $\left(\mathrm{F}_{2}\right) @ 125$ per cent RDF which registered the highest fruit set plant $(69.21 \%)$. This was followed by the fertilizer level $\left(\mathrm{F}_{1}\right) @$ recommended dose of fertilizers which resulted in 66.18 per cent fruit set per plant. The highest dose of fertilizer level $\left(\mathrm{F}_{3}\right)$ i.e 150 per cent RDF supplied to the plant resulted in the lowest percentage of fruit set per plant (65.57).

Due to interaction effect of irrigation and fertilizer levels it was revealed that the fruit set percentage varied significantly with the highest being recorded in the plants receiving irrigation and fertilizer level $\left(\mathrm{I}_{3} \mathrm{~F}_{2}\right)$ @ 50\%, $80 \%$ and $100 \%$ E pan with 125 per cent RDF 
(79.65\%). This was followed by the treatment $\mathrm{I}_{3} \mathrm{~F}_{3}$ i.e $50 \%, 80 \%$ and $100 \%$ E pan with fertilizer level @ 150 per cent RDF, in which there was 74.19 per cent fruit set in the plants. The lowest fruit set $(59.70 \%)$ was observed in the plants receiving irrigation level @ 30\%, 50\% and 60\% E pan + recommended dose of fertilizers $\left(\mathrm{I}_{1} \mathrm{~F}_{1}\right)$.

Percentage of fruit set in a given period of time i.e during the observation interval of every three months, though not recorded, there could be an influence by weather parameters, especially under open field conditions. This is evident when the total number of flowers produced in a period of eighteen months was substantially higher compared to number of matured fruits harvested. This may not be the case under protected conditions, where influence of highspeed wind, high down pour at times and wet conditions over a period of time may not happen any time to have the influence of these weather parameters on fruit set - fruit retention. Often it is recorded in the farmer fields, grown under open conditions that, the farmers lose papaya crop heavily due to extremity of weather especially stormy wind during pre-monsoon showers.

\section{Number of fruits per plant under open field condition}

The plants receiving irrigation level $\left(\mathrm{I}_{3}\right)$ @ $50 \%, 80 \%$ and $100 \% \mathrm{E}$ pan resulted in significantly the highest number of fruits per plant (40.96) followed by irrigation level $\left(\mathrm{I}_{4}\right)$ @ 60\%, 90\% and 120\% E pan provided to the plant (40.66 fruits/plant). However, these treatments were on par with each other. The lowest number of fruits per plant (29.40) was noticed in the plants receiving irrigation level @ 30\%, 50\% and 60\% E pan ( $\left.\mathrm{I}_{1}\right)$. Plants receiving the highest fertilizer dose $\left(\mathrm{F}_{3}\right)$ @ 125 per cent RDF resulted in significantly the highest number of fruits per plant (38.28) and this was followed by the treatment $F_{2}$ i.e recommended dose of fertilizers (36.17 fruits/plant). The lowest number of fruits per plant (33.99) was obtained due to the application of 75 per cent $\mathrm{RDF}\left(\mathrm{F}_{1}\right)$.

The interaction effect of different irrigation and fertilizer levels showed a significant influence on number of fruits per plant. The plants receiving $\mathrm{I}_{4} \mathrm{~F}_{3}$ i.e60\%, $90 \%$ and $120 \%$ E pan +125 per cent RDF registered 43.17 fruits per plant. The number of fruits per plant (44.04) was obtained due to the interaction effect of $\mathrm{I}_{3} \mathrm{~F}_{3}$ i.e $50 \%, 80 \%$ and $100 \% \mathrm{E}$ pan + 125 per cent RDF. The lowest number of fruits per plant (27.93) was recorded in the treatment combination of irrigation @ $30 \%, 50 \%$ and $80 \%$ E pan combined with 75 per cent $\mathrm{RDF}\left(\mathrm{I}_{1} \mathrm{~F}_{1}\right)$ and the result are depicted in Fig 1.

\section{Number of fruits per plant under protected condition}

The lowest number of fruits produced per plant (46.23) in a period of 540 days after transplanting was recorded in the treatment $\left(\mathrm{I}_{1}\right)$ i.e irrigation @ 30\%,50\% and 60\% E pan and whereas, the highest number of fruits (63.76) per plant was recorded in the irrigation level $\left(\mathrm{I}_{3}\right)$ i.e $50 \%, 80 \%$ and $100 \% \mathrm{E}$ pan. This was followed by the papaya plants producing 59.30 fruits per plant providing irrigation $\left(\mathrm{I}_{4}\right) @ 60 \%, 90 \%$ and $120 \%$ E pan. Plants receiving medium dose of fertilizers $\left(\mathrm{F}_{2}\right)$ @ 125 per cent RDF resulted in significantly the highest number of fruits per plant (57.59) followed by fertilizer level $\left(\mathrm{F}_{3}\right)$ i.e 150 per cent RDF (55.59). The lowest number of fruits per plant (53.70) was recorded in the plants receiving recommended dose of fertilizers $\left(\mathrm{F}_{1}\right)$.

The data subjected to statistical analysis with regards to interaction effect of irrigation and fertilizer levels revealed that significantly the 
highest number of fruits per plant (66.98) was noticed in the papaya plants with the application of irrigation @ 50\%,80\% 100\% E pan combined with 125 per cent $\mathrm{RDF}\left(\mathrm{I}_{3} \mathrm{~F}_{2}\right)$. The next best treatment combination was $\mathrm{I}_{3} \mathrm{~F}_{3}$ i.e $50 \%, 80 \%$ and $100 \% \mathrm{E}$ pan +150 per cent RDF which resulted in, on average, 63.14 fruits per plant. The lowest number of fruits (44.26/plant) was recorded in the plants provided with irrigation + fertilizers @ 30\%, $50 \%$ and $60 \% \mathrm{E}$ pan and recommended dose of fertilizers $\left(\mathrm{I}_{1} \mathrm{~F}_{1}\right)$ under protected condition.

\section{Fruit yield per plant (kg) under open field condition}

The effect of various levels of irrigation and fertilizers proved significant in terms of papaya fruit yield per plant and data are presented in Table 1 and depicted in Fig 1. The plants of papaya $c v$. Red lady irrigated @ $50 \%, 80 \%$ and $100 \% \mathrm{E}$ pan $\left(\mathrm{I}_{3}\right)$ registered significantly the highest fruit yield per plant $(37.78 \mathrm{~kg})$. This was followed by irrigation level $\left(\mathrm{I}_{4}\right)$ i.e60\%, 90\% and $120 \% \mathrm{E}$ pan in which the plants registered on an average $35.48 \mathrm{~kg}$ fruits per plant. The lowest fruit yield per plant $(32.52 \mathrm{~kg})$ was noticed in the irrigation level @ 30\%,50\% and 60\% E pan $\left(\mathrm{I}_{1}\right)$. In the plants provided with different fertilizer levels, it was observed that 125 per cent $\mathrm{RDF}\left(\mathrm{F}_{3}\right)$ produced the highest fruit yield per plant $(36.02 \mathrm{~kg})$ followed by fertilizer level $\mathrm{F}_{2}$ i.erecommended dose of fertilizers (34.94 kg/plant). The lowest fruit yield per plant $(33.60 \mathrm{~kg})$ was recorded in fertilizer level @ 75 per cent RDF $\left(F_{1}\right)$.

The interaction effect revealed that the lowest fruit yield per plant $(31.56 \mathrm{~kg})$ was noticed in the plants provided with irrigation@30\%, $50 \%$ and $60 \%$ E pan combined with application of 75 per cent $\operatorname{RDF}\left(\mathrm{I}_{1} \mathrm{~F}_{1}\right)$. The highest fruit yield per plant $(39.64 \mathrm{~kg})$ observed in the treatment combination i.e $50 \%, 80 \%$ and $100 \% \mathrm{E}$ pan and 125 per cent RDF $\left(\mathrm{I}_{3} \mathrm{~F}_{3}\right)$. This was followed by the treatment $\mathrm{I}_{3} \mathrm{~F}_{2}$ i.e $50 \%, 80 \%$ and $100 \% \mathrm{E}$ pan + recommended dose of fertilizers (37.30 $\mathrm{kg}$ /plant). This was on par with $\mathrm{I}_{4} \mathrm{~F}_{3}$ i.e irrigation@50\%,80\% and 100\% E pan + RDF (37.13 kg/plant) under open conditions.

\section{Fruit yield per plant (kg) under protected condition}

The highest yield per plant $(74.98 \mathrm{~kg})$ was recorded with the application of irrigation through drip@50\%,80\% and 100\% E pan $\left(\mathrm{I}_{3}\right)$. The next best treatment effect was with irrigation level@60\%,90\% and 120\% E pan which registered $67.58 \mathrm{~kg}$ per plant and the lowest yield per plant $(63.14 \mathrm{~kg})$ was observed in irrigation level @ 30\%,50\% and $80 \% \mathrm{E}$ pan $\left(\mathrm{I}_{1}\right)$. The effect of fertilizers on yield of papaya fruits per plant revealed that an average yield per plant $(69.58 \mathrm{~kg})$ was obtained in the plants provided with fertilizer level @ 125 per cent $\operatorname{RDF}\left(\mathrm{F}_{2}\right)$, which was followed by $\mathrm{F}_{3}$ level of fertilizer @ 150 per cent RDF (67.85 kg/plant). The lowest fruit yield per plant $(66.99 \mathrm{~kg})$ was noticed in the lowest level of fertilizers $\left(F_{1}\right)$ used in the present investigation i.e recommended dose of fertilizers.

A statistically significant yield of $77.70 \mathrm{~kg}$ per plant was recorded in the plants receiving irrigation@ $@ 50 \%, 80 \%$ and 100\% E pan + fertilizer@125 per cent RDF $\left(\mathrm{I}_{3} \mathrm{~F}_{2}\right)$. This was followed by the treatment combination $\mathrm{I}_{3} \mathrm{~F}_{3} \mathrm{i} . \mathrm{e} 50 \%, 80 \%$ and $100 \% \mathrm{E}$ pan and 150 per cent RDF (73.87 kg/ plant). This was also on par with $\mathrm{I}_{3} \mathrm{~F}_{1}$ i.e50\%, $80 \%$ and $100 \%$ E pan and recommended dose of fertilizers (73.38 $\mathrm{kg} /$ plant). However, at the lowest level of irrigation i.e. $30 \%, 50 \%$ and $60 \% \mathrm{E}$ pan + $\operatorname{RDF}\left(\mathrm{I}_{1} \mathrm{~F}_{1}\right)$, an average yield of $61.52 \mathrm{~kg}$ per plant could be obtained over a period of eighteen months from the date of transplanting under protected condition. 
Form the above observation it could be noticed that the presence and absence of fruit in nodal region may be due to physiological reason rather than failure of fruit set. Because large number of fruits are in the various stages of fruit development at a given time in papaya. Seasonal variation in temperature and humidity may also have an influence on fruit retention immediately after fruit set. The above observations clearly indicated that the performance of papaya $c v$. Red lady under polyhouse condition could register higher yield when compared to open field conditions. Though statically not interpreted, there was a huge yield difference of 61.52 to 77.70 more yield per plant compared to open grown plants.

The reason is obvious that internodal length in polyhouse grown plants is more. This could be an added advantage for developing fruits, in terms of reduced hibernation of sucking pests which otherwise would have affected the appearance due to insect damage and black spots on fruit surfaces. This was more observed in fruits produced under open field conditions.

\section{Yield per hectare (tons) under open field} condition

The papaya plants receiving irrigation level $\left(\mathrm{I}_{3}\right) @ 50 \%, 80 \%$ and $100 \%$ E pan gave significantly the highest yield per hectare (116.60 tonnes). An yield of 109.49 tonnes per hectare was achieved with the irrigation level $\left(\mathrm{I}_{4}\right)$ at $60 \%, 90 \%$ and $120 \% \mathrm{E}$ pan. The lowest level of irrigation i.e $30 \%, 50 \%$ and $60 \% \mathrm{E}$ pan resulted in the lowest yield (100.34 tonnes/ha) as compared to higher levels of irrigation. Similarly, the plants supplied with fertilizers $\left(\mathrm{F}_{3}\right) @ 125$ per cent RDF gave the highest yield (111.15 tonnes/ha), while the plants provided with fertilizer level at recommended dose of fertilizers gave 107.83 tonnes per hectare. The lower yield per hectare (103.67 tons) was noticed in the plants provided with 75 per cent $\operatorname{RDF}\left(\mathrm{F}_{1}\right)$.

The interaction effect of different irrigation and fertilizer levels revealed that the treatment $\mathrm{I}_{3} \mathrm{~F}_{3}$ i.e. $50 \%, 80 \%$ and $100 \% \mathrm{E}$ pan +125 per cent RDF resulted in significantly the highest fruit yield per hectare (122.32 tons).This was followed by the treatment $\left(\mathrm{I}_{3} \mathrm{~F}_{2}\right) @ 50 \%, 80 \%$ and $100 \%$ E pan combined with recommended dose of fertilizers (115.11 t/ha). This was on par with treatment combination $\mathrm{I}_{4} \mathrm{~F}_{3}$ i.e $60 \%, 90 \%$ and $120 \%$ E pan +125 per cent RDF (114.57 $\mathrm{t} / \mathrm{ha})$. The lowest yield per hectare (97.40 tons) was in the treatment combination of irrigation@ @30\%, 50\% and 60\% E pan and 75 per cent $\mathrm{RDF}\left(\mathrm{I}_{1} \mathrm{~F}_{1}\right)$.

\section{Yield per hectare (tons/ha) under protected condition}

The effect of various levels of irrigation and fertilizers had proved significant influence on papaya fruit yield per hectare which has been presented in Table 2 and depicted in Fig 2. There was a significant difference in fruit yield per hectare of papaya $c v$. Red Lady due to varied irrigation levels. The fruit yield per hectare was the highest (231.40 tons) in irrigation level @ 50\%,80\% and 100\% E pan $\left(\mathrm{I}_{3}\right)$, followed by irrigation level $\left(\mathrm{I}_{4}\right)$ i.e $60 \%$, $90 \%$ and $120 \%$ E pan (208.54 t/ha). The lowest yield per hectare (194.86 t/ha) was noticed in irrigation level $\left(\mathrm{I}_{1}\right)$ @ 30\%, 50\% and $60 \% \mathrm{E}$ pan. With respect to different fertilizer levels, as high as 214.72 tons per hectare could be achieved with the application of 125 per cent recommended dose of fertilizers $\left(\mathrm{F}_{2}\right)$ and this was followed by the plants supplied @ 150 per cent RDF (209.39 t/ha). The lowest yield (206.74 t/ha) was obtained with the recommended dose of fertilizer $\left(\mathrm{F}_{3}\right)$. 
The interaction effect of irrigation and fertilizer levels on yield per hector revealed that an estimated yield per hectare was the highest (239.77 tons) with the application of irrigation@ $@ 50 \%, 80 \%$ and 100\% E pan +125 per cent recommended dose of fertilizer $\left(\mathrm{I}_{4} \mathrm{~F}_{2}\right)$. This was followed by 226.45 tons per hectare obtained due to interaction effect of irrigation and fertilizers $\mathrm{I}_{3} \mathrm{~F}_{3}$ i.e $50 \%, 80 \%$ and $100 \% \mathrm{E}$ pan and 150 per cent recommended dose of fertilizers. However, the lowest yield per hectare (189.86 t/ha) was recorded in the plants receiving the treatment combination of irrigation and fertilizers $\left(\mathrm{I}_{1} \mathrm{~F}_{1}\right)$ @ 30\%,50\% and $80 \% \mathrm{E}$ pan + recommended dose of fertilizers.

From the above observations made under the headings, though the estimated yield were indicated under open and protected condition, the marketable quality and shape of fruits is also important from the consumers point of view as well as better unit price and economical benefit to papaya growers. The viral infection (PRSV) was much severe under open conditions in spite of regular plant protection measures taken up against vectors. This is more discussed under the heading pest incidence and management aspect taken up during the investigation.

If the incidence of PRSV is avoided up to initial 5-6 months of growth in papaya, then the plants develop certain tolerance against virus by which initial crop and harvests up to 12 months could be invariably good. Once the plants again become more prone to PRSV incidence, than the crop yield, quality, shape and appearance also get affected. This was more evident in the plants grown in open fields when compared to protected conditions in the present investigation. Such observation and effects were also reported by Lakshminarayana Reddy, (2000), Kunkalikar et al., (2007), Mallikarjun (2009) and Vinayakumar Reddy et al., (2011).
The overall incidence of pest and PRSV under polyhouse is greatly reduced because of the protection against the movement of insect pests (especially sucking insects) through the insect proof nets. The inbuilt insect proof nets up to a height of 3 meters all around the poly house might have given enough protection. A similar observation has been made by those who took up studies on performance of papaya under protected condition. Such influences were also reported by Lakshminarayana Reddy (2000).

Papaya ring spot virus is mainly transmitted through insect vector i.e aphids (sucking pest). When moves from virus infected plant to healthy plants. Under polyhouse conditions, the management of this vector is much easier when compared to other sucking pests like whitefly. For example, in Gerbera a popular commercial crop grown in polyhouse, once infested by whitefly it multiplies so rapidly that no amount of plant protection measures could prevent its spread as reported by many workers (Yadav et al., 2011, Kumar et al., 2010).

One logical thinking, perhaps erecting insect proof nets up to certain heights all around the papaya cropped area, under open conditions, might give protection against insect vectors which transmit virus from plant to plant. This is a fact that sucking pests keep flying at lower heights only (up to 1.5 meter). In case, this practicality works out, then the cost of polyhouse structures and investments could be saved. Similar observations were made by various workers (Mallikarjun, 2009 and Vinayakumar Reddy et al., 2011).

Commercial cultivation of papaya through drip fertigation under open field conditions, though invariably promoted, the chances of crop damage during heavy storms and down pour during pre-monsoon and monsoon seasons cannot be avoided. Further, if proper 
drainage system is not provided, diseases like collar rot, downy mildew etc. may devastate the crop. To avoid all these predicaments, protected cultivation of papaya appears to be safe and productive as evidenced in the present investigation. Similar observations were reported by various workers like (Andrade et al., 1995, Espino de Paz et al., 1995, Hegde, 1998, Galan Sauco, 2002).

In papaya $c v$. Red lady used in the present investigation. The type of fruits produced in these two kinds of population were also different in terms of appearance, shape and seediness. The plants with bisexual flowers produced oblong shaped fruits with seeds inside, while the plants with separate male and female flowers produced typical round shaped seedless fruits which is sold in the market as Red lady. Hence, consumers point of view also this type is important. Whether it is possible to identify actual Red lady plant type in the seedling stage itself? If so, there could be an added advantage of production only typical Red lady type fruits which will have better price and keeping quality as well (Veerannah and Selvaraj, 1984).

Under open field as well as protected condition, there was a multiple fruit setting in a node at later stages (12-14 month onwards) of plant growth and development. This was more evident in the plants grown in open condition. The reason could be more than one bisexual or female flower production in per node. This would have resulted in all the flowers setting into fruits. This is rather disadvantageous due to development of tiny fruits which can have no preference in the market. However, this abnormality appeared at later stages of crop growth and development perhaps which needs special attention with regards to maintaining plant vigour by appropriate plant nutrition, maintainace and plant protection measures. However, this aspect needs further investigation. Similar observations were reported by workers Galan Sauco (2002).

In general yield parameters like number of flowers per plant, number of fruits per plant, percentage of fruit set, fruit weight, fruit yield per plant and fruit yield per hectare were recorded in upto a period 18 months i.e 540 days. Increased number of flowers per plants and others yield parameters observed under higher irrigation and fertilizer levels i.e $60 \%, 90 \%$ and $120 \%$ E pan +150 per cent RDF under polyhouse condition. Might be due to increased water availability and nutrient use efficiency which in turn enhanced rate of cell division and cell enlargement, and increased production of flower inducing hormones through enzymatic activities.

The adequate availability of nutrient might have also helped for better flower bud differentiation, primordial development and ultimately increased flower production in papaya. The present inference is in agreement with the results of Veerannah and Selvaraj, 1984, Kumar et al., 2010 who also reported similar findings.

Though there was higher percentage of increased yield attributing parameters at the highest level of irrigation and fertilizer under protected conditions, The number of fruits per plant, fruit yield per plant and fruit yield per hectare recorded in the level of irrigation and fertilizers i.e $50 \%, 80 \%$ and $100 \% \mathrm{E}$ pan + 125 per cent RDF under open field as well as protected conditions were found optimum as there was no significant difference with the result obtained at higher level of irrigation and fertilizer treatments. Further, split application of fertilizers at fortnightly interval upto 18 months might have favoured the increased uptake of nutrients, more synthesis and translocation of photosynthates and thereby achieving higher economical yield. 
Table.1 Effect of different levels of irrigation and fertilizer on yield parameter of Papaya ( $c v$. Red Lady) under open field condition

\begin{tabular}{|c|c|c|c|c|c|}
\hline Treatments & $\begin{array}{l}\text { Number of } \\
\text { flower plant }\end{array}$ & $\begin{array}{c}\text { Fruit set } \\
\text { percentage }\end{array}$ & $\begin{array}{l}\text { Number of fruits } \\
\text { per plant }\end{array}$ & $\begin{array}{l}\text { Yield /plant } \\
\quad(\mathrm{kg})\end{array}$ & $\begin{array}{c}\text { Yield } \\
\text { (tons/ha) }\end{array}$ \\
\hline \multicolumn{6}{|c|}{ Irrigation levels } \\
\hline $\mathrm{I}_{1}$ & 56.12 & 52.37 & 29.40 & 32.52 & 100.34 \\
\hline $\mathrm{I}_{2}$ & 58.84 & 57.02 & 33.55 & 33.62 & 103.77 \\
\hline $\mathrm{I}_{3}$ & 61.40 & 66.67 & 40.96 & 37.78 & 116.60 \\
\hline $\mathrm{I}_{4}$ & 64.21 & 63.29 & 40.66 & 35.48 & 109.49 \\
\hline S.Em \pm & 0.117 & 0.202 & 0.18 & 0.079 & 0.245 \\
\hline $\mathrm{CD}$ at $5 \%$ & 0.344 & 0.593 & 0.53 & 0.233 & 0.719 \\
\hline \multicolumn{6}{|c|}{ Fertilizer level } \\
\hline$F_{1}$ & 58.84 & 57.58 & 33.99 & 33.60 & 103.67 \\
\hline $\mathrm{F}_{2}$ & 59.70 & 60.38 & 36.17 & 34.94 & 107.83 \\
\hline $\mathrm{F}_{3}$ & 61.88 & 61.56 & 38.28 & 36.02 & 111.15 \\
\hline S.Em \pm & 0.101 & 0.175 & 0.158 & 0.069 & 0.212 \\
\hline $\mathrm{CD}$ at $5 \%$ & 0.298 & 0.514 & 0.463 & 0.202 & 0.623 \\
\hline \multicolumn{6}{|c|}{ Irrigation X Fertilizer level } \\
\hline $\mathrm{I}_{1} \mathrm{~F}_{1}$ & 55.02 & 50.76 & 27.93 & 31.56 & 97.40 \\
\hline $\mathrm{I}_{1} \mathrm{~F}_{2}$ & 56.32 & 52.27 & 29.44 & 32.68 & 100.85 \\
\hline $\mathrm{I}_{1} \mathrm{~F}_{3}$ & 57.02 & 54.09 & 30.84 & 33.31 & 102.79 \\
\hline $\mathrm{I}_{2} \mathrm{~F}_{1}$ & 58.39 & 54.17 & 31.63 & 32.90 & 101.51 \\
\hline $\mathrm{I}_{2} \mathrm{~F}_{2}$ & 59.00 & 57.59 & 33.98 & 33.98 & 104.86 \\
\hline $\mathrm{I}_{2} \mathrm{~F}_{3}$ & 59.12 & 59.29 & 35.05 & 34.00 & 104.92 \\
\hline $\mathrm{I}_{3} \mathrm{~F}_{1}$ & 59.67 & 64.92 & 38.74 & 36.42 & 112.38 \\
\hline $\mathrm{I}_{3} \mathrm{~F}_{2}$ & 60.29 & 66.53 & 40.11 & 37.30 & 115.11 \\
\hline $\mathrm{I}_{3} \mathrm{~F}_{3}$ & 64.23 & 68.57 & 44.04 & 39.64 & 122.32 \\
\hline $\mathrm{I}_{4} \mathrm{~F}_{1}$ & 62.29 & 60.44 & 37.65 & 33.51 & 103.41 \\
\hline $\mathrm{I}_{4} \mathrm{~F}_{2}$ & 63.19 & 65.12 & 41.15 & 35.80 & 110.48 \\
\hline $\mathrm{I}_{4} \mathrm{~F}_{3}$ & 67.14 & 64.30 & 43.17 & 37.13 & 114.57 \\
\hline S.Em \pm & 0.20 & 0.35 & 0.32 & 0.14 & 0.42 \\
\hline $\mathrm{CD}$ at $5 \%$ & 0.60 & 1.03 & 0.93 & 0.40 & 1.25 \\
\hline
\end{tabular}

\begin{tabular}{|c|c|c|c|c|c|}
\hline $\begin{array}{c}\text { Irrigation } \\
\text { levels (E pan) }\end{array}$ & $\begin{array}{c}\mathbf{1 - 4} \\
\text { Months }\end{array}$ & $\begin{array}{c}\mathbf{5 - 9} \\
\text { Months }\end{array}$ & $\begin{array}{c}\mathbf{1 0 - 1 4} \\
\text { Months }\end{array}$ & $\begin{array}{c}\text { Fertilizer } \\
\text { levels }\end{array}$ & RDF \\
\hline $\mathbf{I}_{\mathbf{1}}$ & $30 \%$ & $50 \%$ & $60 \%$ & $\mathrm{~F}_{1}$ & $75 \% \mathrm{RDF}$ \\
\hline $\mathbf{I}_{\mathbf{2}}$ & $40 \%$ & $60 \%$ & $80 \%$ & $\mathrm{~F}_{2}$ & $100 \% \mathrm{RDF}$ \\
\hline $\mathbf{I}_{\mathbf{3}}$ & $50 \%$ & $80 \%$ & $100 \%$ & $\mathrm{~F}_{3}$ & $125 \% \mathrm{RDF}$ \\
\hline $\mathbf{I}_{\mathbf{4}}$ & $60 \%$ & $90 \%$ & $120 \%$ & & \\
\hline
\end{tabular}

E pan: Pan evapotranspiration.

RDF: Recommended dose of fertilizer (250:250:500 g NPK/Plant/Year) 
Table.2 Papaya ( $c v$. Red Lady) as influenced by different irrigation and fertilizer levels on yield parameters under protected condition

\begin{tabular}{|c|c|c|c|c|c|}
\hline Treatments & $\begin{array}{l}\text { Number of } \\
\text { flower plant }\end{array}$ & $\begin{array}{l}\text { Fruit set } \\
\text { percentage }\end{array}$ & $\begin{array}{c}\text { Number of } \\
\text { fruits per plant }\end{array}$ & $\begin{array}{c}\text { Yield } \\
\text { /plant (kg) }\end{array}$ & $\begin{array}{c}\text { Yield } \\
\text { (tons/ha) }\end{array}$ \\
\hline \multicolumn{6}{|c|}{ Irrigation levels } \\
\hline $\mathrm{I}_{1}$ & 77.21 & 59.88 & 46.23 & 63.14 & 194.86 \\
\hline $\mathrm{I}_{2}$ & 81.25 & 65.50 & 53.22 & 66.86 & 206.33 \\
\hline $\mathrm{I}_{3}$ & 84.09 & 75.82 & 63.76 & 74.98 & 231.40 \\
\hline $\mathrm{I}_{4}$ & 88.85 & 66.76 & 59.30 & 67.58 & 208.54 \\
\hline S.Em \pm & 0.15 & 0.20 & 0.23 & 0.156 & 0.48 \\
\hline $\mathrm{CD}$ at $5 \%$ & 0.46 & 0.61 & 0.69 & 0.456 & 1.40 \\
\hline \multicolumn{6}{|c|}{ Fertilizer levels } \\
\hline $\mathrm{F}_{1}$ & 80.88 & 66.18 & 53.70 & 66.99 & 206.74 \\
\hline $\mathrm{F}_{2}$ & 83.03 & 69.21 & 57.59 & 69.58 & 214.72 \\
\hline $\mathrm{F}_{3}$ & 84.64 & 65.57 & 55.59 & 67.85 & 209.39 \\
\hline S.Em \pm & 0.13 & 0.18 & 0.20 & 0.135 & 0.41 \\
\hline $\mathrm{CD}$ at $\overline{5 \%}$ & 0.40 & 0.53 & 0.60 & 0.395 & 1.21 \\
\hline \multicolumn{6}{|c|}{ Irrigation X Fertilizer levels } \\
\hline $\mathrm{I}_{1} \mathrm{~F}_{1}$ & 74.14 & 59.70 & 44.26 & 61.52 & 189.86 \\
\hline $\mathrm{I}_{1} \mathrm{~F}_{2}$ & 78.20 & 61.74 & 48.28 & 64.70 & 199.65 \\
\hline $\mathrm{I}_{1} \mathrm{~F}_{3}$ & 79.29 & 58.19 & 46.14 & 63.21 & 195.07 \\
\hline $\mathrm{I}_{2} \mathrm{~F}_{1}$ & 80.03 & 64.51 & 51.63 & 66.09 & 203.94 \\
\hline $\mathrm{I}_{2} \mathrm{~F}_{2}$ & 81.06 & 66.68 & 54.05 & 67.56 & 208.50 \\
\hline $\mathrm{I}_{2} \mathrm{~F}_{3}$ & 82.66 & 65.30 & 53.98 & 66.94 & 206.56 \\
\hline $\mathrm{I}_{3} \mathrm{~F}_{1}$ & 83.07 & 73.61 & 61.15 & 73.38 & 226.45 \\
\hline $\mathrm{I}_{3} \mathrm{~F}_{2}$ & 84.09 & 79.65 & 66.98 & 77.70 & 239.77 \\
\hline $\mathrm{I}_{3} \mathrm{~F}_{3}$ & 85.11 & 74.19 & 63.14 & 73.87 & 227.97 \\
\hline $\mathrm{I}_{4} \mathrm{~F}_{1}$ & 86.29 & 66.91 & 57.74 & 66.98 & 206.70 \\
\hline $\mathrm{I}_{4} \mathrm{~F}_{2}$ & 88.78 & 68.75 & 61.04 & 68.36 & 210.97 \\
\hline $\mathrm{I}_{4} \mathrm{~F}_{3}$ & 91.48 & 64.62 & 59.11 & 67.39 & 207.95 \\
\hline S.Em \pm & 0.27 & 0.36 & 0.41 & 0.27 & 0.83 \\
\hline $\mathrm{CD}$ at $5 \%$ & 0.81 & 1.06 & 1.20 & 0.79 & 2.44 \\
\hline
\end{tabular}

\begin{tabular}{|c|c|c|c|c|c|}
\hline $\begin{array}{c}\text { Irrigation } \\
\text { levels (E pan) }\end{array}$ & $\begin{array}{c}\mathbf{1 - 4} \\
\text { Months }\end{array}$ & $\begin{array}{c}\mathbf{5 - 9} \\
\text { Months }\end{array}$ & $\begin{array}{c}\mathbf{1 0 - 1 4} \\
\text { Months }\end{array}$ & $\begin{array}{c}\text { Fertilizer } \\
\text { levels }\end{array}$ & RDF \\
\hline $\mathbf{I}_{\mathbf{1}}$ & $30 \%$ & $50 \%$ & $60 \%$ & $\mathrm{~F}_{1}$ & $100 \%$ RDF \\
\hline $\mathbf{I}_{\mathbf{2}}$ & $40 \%$ & $60 \%$ & $80 \%$ & $\mathrm{~F}_{2}$ & $125 \%$ RDF \\
\hline $\mathbf{I}_{\mathbf{3}}$ & $50 \%$ & $80 \%$ & $100 \%$ & $\mathrm{~F}_{3}$ & $150 \%$ RDF \\
\hline $\mathbf{I}_{\mathbf{4}}$ & $60 \%$ & $90 \%$ & $120 \%$ & & \\
\hline
\end{tabular}

E pan: Pan evapotranspiration.

RDF: Recommended dose of fertilizer (250:250:500 g NPK/Plant/Year) 
Table.3 Economics of cultivation of Papaya ( $c v$. Red Lady) under open field condition (Eighteen months duration)

\begin{tabular}{|c|c|c|c|c|c|}
\hline $\begin{array}{c}\text { Treatment } \\
\text { combinations }\end{array}$ & $\begin{array}{c}\text { Total yield per ha } \\
\text { (tons) }\end{array}$ & $\begin{array}{c}\text { Gross return } \\
\text { (Rs.) }\end{array}$ & $\begin{array}{c}\text { Total cost of } \\
\text { cultivation (Rs.) }\end{array}$ & $\begin{array}{c}\text { Net return } \\
\text { (Rs.) }\end{array}$ & C:B ratio \\
\hline $\mathbf{I}_{\mathbf{1}} \mathbf{F}_{\mathbf{1}}$ & 97400 & 1461000 & 761526 & 699474 & $1: 1.92$ \\
\hline $\mathbf{I}_{\mathbf{1}} \mathbf{F}_{\mathbf{2}}$ & 100850 & 1512750 & 775698 & 737052 & $1: 1.95$ \\
\hline $\mathbf{I}_{\mathbf{1}} \mathbf{F}_{\mathbf{3}}$ & 102790 & 1541850 & 779536 & 762314 & $1: 1.98$ \\
\hline $\mathbf{I}_{\mathbf{2}} \mathbf{F}_{\mathbf{1}}$ & 101510 & 1522650 & 761526 & 761124 & $1: 2.00$ \\
\hline $\mathbf{I}_{\mathbf{2}} \mathbf{F}_{\mathbf{2}}$ & 104860 & 1572900 & 775698 & 797202 & $1: 2.03$ \\
\hline $\mathbf{I}_{\mathbf{2}} \mathbf{F}_{\mathbf{3}}$ & 104920 & 1573800 & 779536 & 794264 & $1: 2.02$ \\
\hline $\mathbf{I}_{\mathbf{3}} \mathbf{F}_{\mathbf{1}}$ & 112380 & 1685700 & 761526 & 924174 & $1: 2.21$ \\
\hline $\mathbf{I}_{\mathbf{3}} \mathbf{F}_{\mathbf{2}}$ & 115110 & 1726650 & 775698 & 950952 & $1: 2.23$ \\
\hline $\mathbf{I}_{\mathbf{3}} \mathbf{F}_{\mathbf{3}}$ & 122320 & 1834800 & 779536 & 1055264 & $1: 2.35$ \\
\hline $\mathbf{I}_{\mathbf{4}} \mathbf{F}_{\mathbf{1}}$ & 103410 & 1551150 & 761526 & 789624 & $1: 2.04$ \\
\hline $\mathbf{I}_{\mathbf{4}} \mathbf{F}_{\mathbf{2}}$ & 110480 & 1657200 & 775698 & 881502 & $1: 2.14$ \\
\hline $\mathbf{I}_{\mathbf{4}} \mathbf{F}_{\mathbf{3}}$ & 114570 & 1718550 & 779536 & 939014 & $1: 2.20$ \\
\hline & & & & & \\
\hline
\end{tabular}

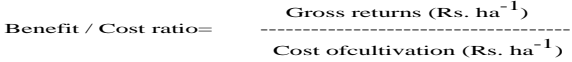

(Note: On an average Papaya fruits were sold at Rs.15 per Kg)

\begin{tabular}{|c|c|c|c|c|c|}
\hline $\begin{array}{c}\text { Irrigation levels } \\
\text { (E pan) }\end{array}$ & $\begin{array}{c}\mathbf{1 - 4} \\
\text { Months }\end{array}$ & $\begin{array}{c}\mathbf{5 - 9} \\
\text { Months }\end{array}$ & $\begin{array}{c}\mathbf{1 0 - 1 4} \\
\text { Months }\end{array}$ & $\begin{array}{c}\text { Fertilizer } \\
\text { levels }\end{array}$ & RDF \\
\hline $\mathbf{I}_{\mathbf{1}}$ & $30 \%$ & $50 \%$ & $60 \%$ & $\mathrm{~F}_{1}$ & $75 \% \mathrm{RDF}$ \\
\hline $\mathbf{I}_{\mathbf{2}}$ & $40 \%$ & $60 \%$ & $80 \%$ & $\mathrm{~F}_{2}$ & $100 \% \mathrm{RDF}$ \\
\hline $\mathbf{I}_{\mathbf{3}}$ & $50 \%$ & $80 \%$ & $100 \%$ & $\mathrm{~F}_{3}$ & $125 \% \mathrm{RDF}$ \\
\hline $\mathbf{I}_{\mathbf{4}}$ & $60 \%$ & $90 \%$ & $120 \%$ & & \multicolumn{1}{|c|}{} \\
\hline
\end{tabular}

E pan: Pan evapotranspiration

RDF: Recommended dose of fertilizer (250:250:500 g NPK/Plant/Year)

Table.4 Economics of cultivation of Papaya ( $c v$. Red Lady) under protected conditions (Eighteen months duration)

\begin{tabular}{|c|c|c|c|c|c|}
\hline $\begin{array}{c}\text { Treatment } \\
\text { combinations }\end{array}$ & Yield per ha (tons) & $\begin{array}{c}\text { Gross return } \\
\text { (Rs.) }\end{array}$ & $\begin{array}{c}\text { cost of } \\
\text { cultivation (Rs) }\end{array}$ & $\begin{array}{c}\text { Net return } \\
\text { (Rs.) }\end{array}$ & $\begin{array}{c}\text { C:B } \\
\text { ratio }\end{array}$ \\
\hline $\mathbf{I}_{\mathbf{1}} \mathbf{F}_{\mathbf{1}}$ & 189860 & 3417480 & 1420169 & 1997311 & $1: 2.41$ \\
\hline $\mathbf{I}_{\mathbf{1}} \mathbf{F}_{\mathbf{2}}$ & 199650 & 3593700 & 1426036 & 2167664 & $1: 2.52$ \\
\hline $\mathbf{I}_{\mathbf{1}} \mathbf{F}_{\mathbf{3}}$ & 195070 & 3511260 & 1432056 & 2079204 & $1: 2.45$ \\
\hline $\mathbf{I}_{\mathbf{2}} \mathbf{F}_{\mathbf{1}}$ & 203940 & 3670920 & 1420169 & 2250751 & $1: 2.58$ \\
\hline $\mathbf{I}_{\mathbf{2}} \mathbf{F}_{\mathbf{2}}$ & 208500 & 3753000 & 1426036 & 2326964 & $1: 2.63$ \\
\hline $\mathbf{I}_{\mathbf{2}} \mathbf{F}_{\mathbf{3}}$ & 206560 & 3718080 & 1432056 & 2286024 & $1: 2.60$ \\
\hline $\mathbf{I}_{\mathbf{3}} \mathbf{F}_{\mathbf{1}}$ & 226450 & 4076100 & 1420169 & 2655931 & $1: 2.87$ \\
\hline $\mathbf{I}_{\mathbf{3}} \mathbf{F}_{\mathbf{2}}$ & 239770 & 4315860 & 1426036 & 2889824 & $1: 3.03$ \\
\hline $\mathbf{I}_{\mathbf{3}} \mathbf{F}_{\mathbf{3}}$ & 227970 & 4103460 & 1432056 & 2671404 & $1: 2.87$ \\
\hline $\mathbf{I}_{\mathbf{4}} \mathbf{F}_{\mathbf{1}}$ & 206700 & 3720600 & 1420169 & 2300431 & $1: 2.62$ \\
\hline $\mathbf{I}_{\mathbf{4}} \mathbf{F}_{\mathbf{2}}$ & 210970 & 3797460 & 1426036 & 2371424 & $1: 2.66$ \\
\hline $\mathbf{I}_{\mathbf{4}} \mathbf{F}_{\mathbf{3}}$ & 207950 & 3743100 & 1432056 & 2311044 & $1: 2.61$ \\
\hline & & & & \\
\hline
\end{tabular}

(Note: On an average Papaya fruits were sold at Rs.18 per Kg) 


\begin{tabular}{|c|c|c|c|c|c|c|}
\hline $\begin{array}{c}\text { Irrigation } \\
\text { levels (E pan) }\end{array}$ & $\begin{array}{c}\mathbf{1 - 4} \\
\text { Months }\end{array}$ & $\begin{array}{c}\mathbf{5 - 9} \\
\text { Months }\end{array}$ & $\begin{array}{c}\mathbf{1 0 - 1 4} \\
\text { Months }\end{array}$ & $\begin{array}{c}\text { Fertilizer } \\
\text { levels }\end{array}$ & RDF \\
\hline $\mathbf{I}_{\mathbf{1}}$ & $30 \%$ & $50 \%$ & $60 \%$ & $\mathrm{~F}_{1}$ & $100 \% \mathrm{RDF}$ \\
\hline $\mathbf{I}_{\mathbf{2}}$ & $40 \%$ & $60 \%$ & $80 \%$ & $\mathrm{~F}_{2}$ & $125 \% \mathrm{RDF}$ \\
\hline $\mathbf{I}_{\mathbf{3}}$ & $50 \%$ & $80 \%$ & $100 \%$ & $\mathrm{~F}_{3}$ & $150 \% \mathrm{RDF}$ \\
\hline $\mathbf{I}_{\mathbf{4}}$ & $60 \%$ & $90 \%$ & $120 \%$ & & & \\
\hline
\end{tabular}

E pan: Pan evapotranspiration

RDF: Recommended dose of fertilizer (250:250:500 g NPK/Plant/Year)

Fig.1 Effect of different levels of irrigation and fertilizer on number of fruits per plants in Papaya ( $c v$. Red Lady) under open field and protected condition

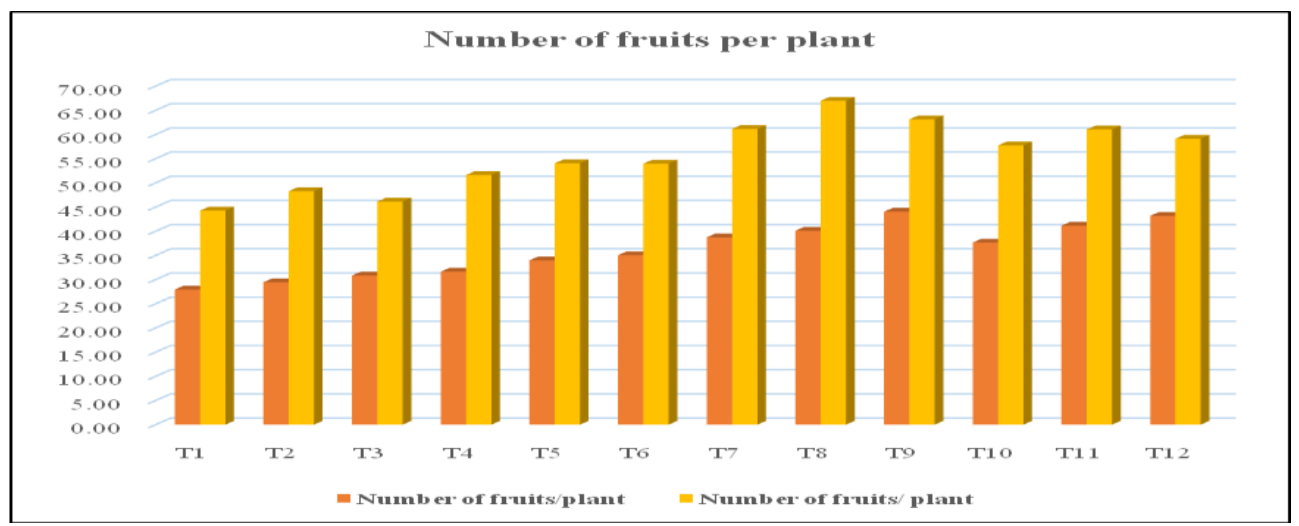

Fig.2 Effect of different levels of irrigation and fertilizer on yield per hectare of Papaya ( $C v$. Red Lady) under open field and protected condition

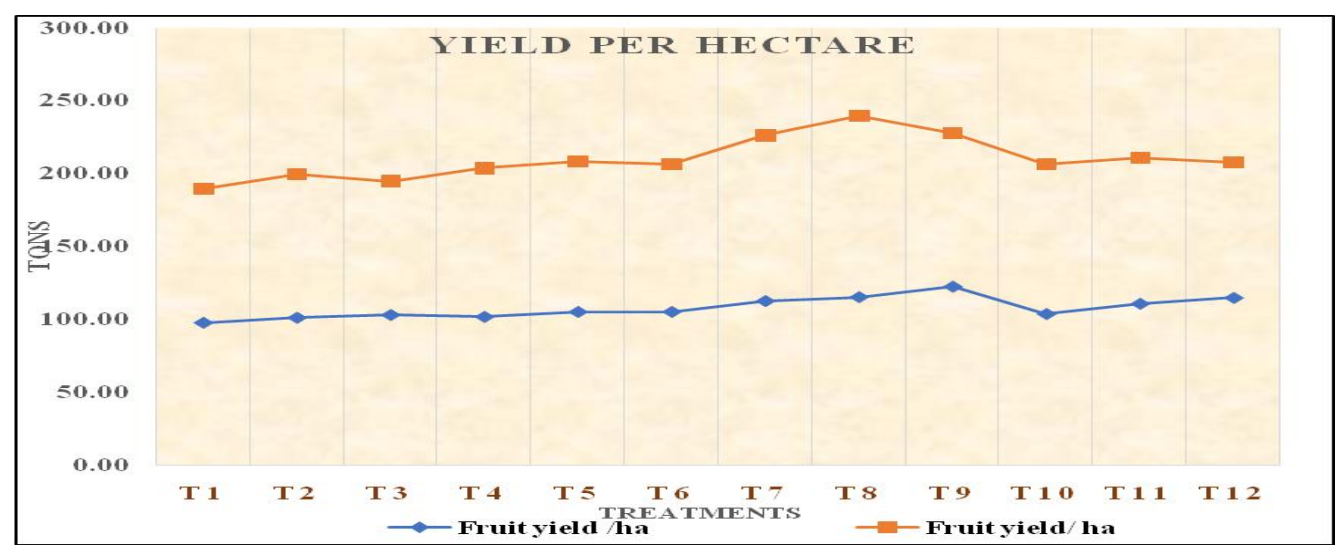

Significant difference was observed under polyhouse average fruit yield per plant $(77.70$ $\mathrm{kg} / \mathrm{plant})$, and yield per (239.77 tons/ha), compared to open field. Where it was recorded fruit yield per plant $(39.64 \mathrm{~kg})$ and yield per hectare (122.32 tons/ha). This may be due to the early flowering, more fruit set and prolonged harvest period, were governed by the climatic factors in protected condition. Similarly reports by Espino de paz et al., 1995.

Galan sauco and Rodriguez Pastor (2007). In poly house, the increased yield recorded 
might be due to the reduced incidence of papaya ring spot virus (PRSV) and other pest damages which lower less compared to open field condition leading to healthy growth, and high number of fruits and enhanced fruiting zone. In polyhouse increased annual yield was due to the absence papaya ring spot virus (PRSV) incidence, continuous and healthy growth, more leaf area, number of fruits and prolonged production with maximum number of harvests. Similarly, (Galan Sauco and Rodriguez pastor 2007, Mallikarjun, 2009 and Vinayakumar Reddy et al., 2011).

The positive influence of higher levels irrigation and fertigation on growth attributes and fruit characteristics ultimately reflected in higher number of fruits per plant, average fruit weight and yield of papaya in these particular treatments in present study. This might be due to the increased in growth traits which helped to increase the synthesis of carbohydrates which utilized for the development of fruits. In the present study, the plant receiving treatment $\mathrm{I}_{3} \mathrm{~F}_{2} 50 \%, 80 \%$ and $100 \%$ E pan +100 and 125 per cent RDF recorded higher number of fruits per plant, fruit yield per plant and fruit yield per hectare over rest of the treatments but, it was at par with treatment $\mathrm{I}_{3} \mathrm{~F}_{3} 50 \%, 80 \%$ and $100 \%$ E pan +125 and 150 per cent RDF and also due to adequate supply of water and reduced weed growth might have resulted in more number of fruits and higher fruit yield of papaya plant under drip irrigation. Similar results were reported by (Kumar et al., 2010, Mahalakshmi et al., 2001b, Mallikarjun, 2009 and Vinayakumar Reddy et al., 2011).

Combination of optimum level of irrigation and fertilizer application @ 50\%, 80\% and $100 \%$ E pan + recommended dose of fertilizer \& 125 RDF per cent RDF helps in development and growth of new cells in plant meristem. These interfere in regulation of $\mathrm{K} / \mathrm{Ca}$ ratio in plants and play key role in translocation of starch, uptake of phosphorous and synthesis of amino acids, and enhance the production of chlorophyll, thylakoid and chloroplast which may be attributed for increased yield attributes. Enhanced production in protected condition might be due controlled environment less leaching of nutrient and more uptake which had beneficial effect on yield attributes like number of flowers, number of fruits, fruit set percentage, yield per plant and yield per hectare. These results are in conformity with Mahalakshmi et al., (2001b) and Kavino et al., (2002).

The higher yield associated with the use of the poly house in comparison with open field conditions. The reduction of radiation is responsible for down-regulation of photosynthetic capacity of leaves and consequently a lower light saturated photosynthetic rate compared to the open field. The response of papaya crop to different irrigation and fertilizer levels on general growth and duration under protected condition seemed to be prolonged. Though statistically not interpreted, there was an increased production and productivity of papaya under protected conditions. Increased yield attributes like number of flowers, number of fruits, fruit set percentage, yield per plant and yield per hectare, prolonged duration of crop were all contributing for increased production and productivity when compared to the same crop grown at same time under open field conditions. There was a congenial weather parameter especially temperature, humidity and reduced wind velocity under protected condition might favored plant to superior growth and yield. Similar result was reported by Kumar et al., (2010), Mallikarjun (2009) and Vinayakumar Reddy et al., (2011).

Present investigation the highest number flowers per plants observed under higher level 
of irrigation and fertilizer $\mathrm{I}_{4} \mathrm{~F}_{3} 60 \%, 90 \%$ and $120 \%$ E pan +125 per cent RDF and 150 per cent RDF but here competition between nutrient and water is more compare to optimum level so, Though the higher number of fruits per plant, fruit yield per plant and fruit yield per hectare the highest in optimum level of irrigation @ 50\%,80\% and 100\% E pan + fertilizer level 125 per cent RDF both open field and protected conditions appeared to be optimum as higher returns were achieved. It might be due to luxury consumption concept it means the tendency of some crops to absorb and accumulate nutrients far in excess of their actual needs if it is present in sufficiently large quantities in the soil.

Potassium is one of the nutrient elements which is subjected to luxury consumption. The absorption pattern of different nutrients by plants is varies greatly among the plant species and also their age and growth stages. Similar result was reported by Kumar et al., (2010).

\section{Influence of different levels of irrigation and fertilizers on cost economics of papaya cv. Red lady under open field and protected conditions}

The effect of different levels of irrigation and fertilizers on cost economics of growing papaya $c v$. Red lady under open field is presented in Table 3 and protected conditions under table 4 , respectively.

\section{Cost economics of papaya under open field conditions}

The cost benefit ratio by growing papaya under open field condition with varied level of irrigation and fertilizers ranged from 1:1.92 to $1: 2.35$ ratios. The highest yield of 122.32 tonnes per hectare was achieved in papaya crop grown under open field with the treatment combinations of $\mathrm{I}_{3} \mathrm{~F}_{3}$ i.e $50 \%, 80 \%$ and $100 \%$ E pan +125 per cent RDF. Though, statistically not interpreted, the gross returns of Rs.18,34,800/- and net returns Rs. $10,55,264 /$ - with a cost benefit ratio of (1:2.35) was observed. The lowest cost benefit ratio (1:1.92) was seen in papaya grown with the application of irrigation water through drip combined with fertilizers i.e. $30 \%, 50 \%$ and $60 \%$ E pan +75 per cent RDF $\mathrm{I}_{1} \mathrm{~F}_{1}$. The cost economics indicated that an irrigation level of $50 \%, 80 \%$ and $100 \%$ E pan combined with $\mathrm{F}_{3}$ level of fertilizers i.e. 125 per cent RDF found to give the highest cost benefit ratio of 1:2.35. It cannot be inferred also that whether further increase in irrigation and fertilizer level could result in still higher cost benefit ratio as most of the growth and yield parameters showed non-significant difference between the highest level of irrigation and fertilizer levels $\left(\mathrm{I}_{4} \mathrm{~F}_{3}\right)$ and the next level of irrigation and fertilizers $\left(\mathrm{I}_{4} \mathrm{~F}_{2}\right)$ experimented in the present investigation.

\section{Cost economics of papaya under protected conditions (Table3)}

The cost benefit ratio by growing papaya under protected condition with varied level of irrigation and fertilizers ranged from 1:2.41 to 1:3.03 ratios. With respect to cost economics under polyhouse condition, significantly the highest yield of 239.77 tons per hectare in papaya was observed with the irrigation and fertilizers@50\%,80\% and 100\% E pan + 125 per cent RDF $\left(\mathrm{I}_{3} \mathrm{~F}_{2}\right)$. The extrapolation of cost of cultivation and returns in terms of value indicated that a gross return of Rs 4315860/- per hectare and net returns of Rs. 2889824/- per hectare could be obtained by realization of the produce. With this a cost benefit ratio of 1:3.03 is possible when papaya crop was raised with optimum level of irrigation and fertilizers. The lowest cost benefit ratio of 1:2.41 was seen in the plants provided with irrigation and fertilizers @ 
$30 \%, 50 \%$ and $60 \%$ E pan with recommended dose of fertilizers $\left(\mathrm{I}_{1} \mathrm{~F}_{1}\right)$.

The cost benefit ratio under protected cultivation was higher when compared to the crop grown under open field conditions. The range of cost benefit ratio varied form 1:2.41 to $1: 3.03$ under protected conditions. Papaya yield was more than 200 per cent under protected conditions compared to open conditions. The less incidence of insect damage and spread of papaya ring spot virus favored the production of more number of marketable quality fruits with good shape and size, upto a period for more than 540 days duration of the crop. This would fetch more price per unit weight and income with high cost benefit ratio. Added to this, uniform soil moisture to the plants and timely and frequent application of macronutrient at optimum level favoured higher yields under poly house conditions. This is not so under open field conditions as the crop invariably affected by vagaries of climatic conditions like varied temperature, high soil moisture content during rainy days, infection by disease organisms etc. Hence, there is a uncertainty in obtaining good yield and quality fruits under open field conditions. These results are in conformity with Mahalakshmi et al., (2001b) and Kavino et al., (2004). Even with consideration of depreciation cost of polyhouse structure, protected cultivation found to give higher net returns as the yield potentiality is double under protected condition compared to open field condition.

Looking at higher investment initially with high cost of polyhouse structure, the recommendation of grown papaya under polyhouse structure may not be appreciable, all of the sudden, in the horticulture sector. However, looking at yield potentiality and quality of papaya $c v$. Red Lady grown under protected condition, many progressive farmers can take up polyhouse cultivation of papaya as a venture in a medium size structure of 500 square meter or maximum in a area of 1000 square meter polyhouse structure. Open field cultivation of Taiwan Red Lady, the most popular variety in the consumers market, is becoming alarmingly difficult due to papaya ring spot virus (PRSV) especially in Karnataka.

\section{References}

Anonymous, 2008, Nutrient and water management through fertigation in papaya. Fourth Meeting of Crop Production Sub Committee of Research Council, April, 9 -10, 2008, pp: 9 - 14.

Andrade, H., Garcia, E., Mora, A., Nieto, D. and Villawveva, A., 1995, Integrated management of papaya ringspot virus in Veracruz, Mexico, Trop. fruits new., 14(3):7-10.

Espino De Paz, A.I., Rodriguez Pastor, M.C. and De leon Rodriguez, M.J., 1995, Detection diagnostic de virosisen papaya(Carica papaya L.) laisla de Tenerife. Phytoma, 73(13):26-30.

Galan Sauco, V. and Rodriguez Pastor, M.C.R., 2007, Greenhouse cultivation of papaya. Acta Hort. 74 (3):191-195.

Kavino, M. Kumar, N. Soorianathasund Aram, K. and Jeyakumar, P., 2002, Effect of sources of fertilizers for fertigation on yield and quality of banana $c v$. Robusta(AAA). South Indian Hort, 55 (6): 301-307.

Kumar, N., Soorianathasundaram, K., Meenakshi, N., Manivannan, M. I., Suresh, J. and Nosov, V., 2010, Balanced Fertilization in papaya for higher yield and quality, Acta Horticulture, 85(8): 357-362.

Kunkalikar, S., 2003, Molecular characterization, cloning of coat protein gene, epidemiology and management of Papaya ringspot virus, 
Ph.D. Thesis, Univ. Agric. Sci., Dharwad, pp. 109

Lakshminarayana Reddy, C. N., 2000, Studies on papaya ringspot virus disease. M.Sc. (Agri.) Thesis, Univ. Agric. Sci., Bangalore, pp. 105.

Mahalakshmi, M., Kumar, N., Jayakumar, P. and Soorianathasundara K. 2001a, Fertigation study in banana under normal system of planting. J. of South Indian Hort., 49 (9): 80-85.

Mahalakshmi, M., Kumar, N., Jayakumar, P. and Soorianatha Sundara K., 2001b, Fertigation study in banana under high density planting system. J. of South Indian Hort.,40 (6): 86-91.

Mallikarjun, Y. K., 2009, Investigations on mild strains and transformation of PRSV-CP gene in Papaya. Ph.D. Thesis, Univ. Agric. Sci., Dharwad. Pp. 121.
Veerannah, L. and Selvaraj, P., 1984, Studies on growth, dry matter partitioning and the pattern of nutrient uptake in papaya. National sem. on papaya and papain production, Tamil Nadu Agricultural University, Coimbatore, pp. 76-78.

Vinayakumar Reddy, P., Nache Gowda, V., Rajesh, A. M., Yathindra, H. A. Andharshavardhan, M., 2011, Survey for the incidence and variability of symptoms on Papaya Ringspot Virus in Southern Karnataka, India. Plant Archives, 11(2): 1147-1149.

Yadav, A. S., Yadav, H. C. and Singh, Y. P., 2011, Effect of integrated nutrient nourishment on yield attributes and economics of papaya (Carica papaya L.) $c v$. Pusa Dwarf. Plant Archives, 12 (1): 307-309.

\section{How to cite this article:}

Vinod Godi, Mahabaleshwar Hegde, A. Vidya, M. N. Thimmegouda, C. T. Subbarayappa, B. Shivanna and Hanamantharaya, B. G. 2020. Influence of Different Levels of Irrigation and Fertilizers on Yield and Cost Economics of Papaya ( $c v$. Red Lady) under Open and Protected Condition. Int.J.Curr.Microbiol.App.Sci. 9(11): 3288-3304. doi: https://doi.org/10.20546/ijcmas.2020.911.394 